\title{
BEYOND REPORTING. MEDIA AGENCY IN TRANSITIONAL JUSTICE PROCESSES
}

\section{AMAIA ÁLVAREZ BERASTEGI}

amaia.alvarez@unavarra.es

Lecturer at the Universidad Pública de Navarra (Spain). PhD in Law at Ulster University, conducted postdoctoral research at the University of the Basque Country. She has published in international journals related to the areas of historical memory, transitional justice, history and journalism.

\begin{abstract}
Despite the significant impact of the media in transitional justice processes, this relationship remains underexplored. The role of the media in building narratives of conflict and past human rights violations was traditionally framed within the dichotomy of promoting peace vs inflicting war. Yet, these roles, as well as the media systems themselves, need to be placed within more complex frameworks. This article analyses some of the key themes that connect transitional justice (the right to truth, justice, reparations and guarantees of non-repetition) and the media. The primary conclusion is that we need to go beyond the role of the media as an observer, and frame it as a possible agent of the overall process of conflict transformation and transitional justice.

\section{Keywords}

Human Rights and Media; Political Violence; Conflict; Transitional Justice; Peace Journalism.

How to cite this article

Berastegi, Amaia Álvarez (2020). "Beyond reporting. Media agency in transitional justice processes". In Janus.net, e-journal of international relations. Vol. 11, No. 2 Consulted [online] at date of last visit, DOI: https://doi.org/10.26619/1647-7251.11.2.9
\end{abstract}

Article received on September 25, 2019 and accepted for publication on April 10, 2020

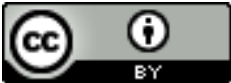




\title{
BEYOND REPORTING. MEDIA AGENCY IN TRANSITIONAL JUSTICE PROCESSES
}

\author{
AMAIA ÁLVAREZ BERASTEGI
}

\section{Introduction}

In the last fifteen years, academia and practitioners have focused with particular emphasis on the politics of the past, and memory and transitional justice studies have proliferated (Teitel 2014). The concept of transitional justice has expanded quickly and closely connected to the area of human rights (Arthur 2009). The right to truth, justice, reparation and guarantees of non-repetition have been widely researched in theory and practice (Olsen et al. 2010; Gready 2010; De Greiff 2012; Buckley-Zisteil and Koloma Beck 2015; McEvoy and Mallinder 2017). Yet, the specific role of the media in transitional justice processes remains largely underexplored (Laplante 2009; Hodzic and Tolbert 2016). This article follows up the work of the few transitional justice scholars who have explored this connection (see, for instance: Laplante 2009; Price and Stremlau 2012; Tamayo and Bonilla 2014; Viebach et al. 2016) and makes a contribution to the conceptualization of the relationship between the fields of the media and transitional justice. The framework used is based on a comprehensive perspective that goes beyond the role of journalists as reporters and understands the media as an actor and focus of transitional justice initiatives. With this aim, the article focuses on several key themes, such as the responsibility of the media in truth processes, the mechanisms for media accountability and reparation programmes for journalists.

The vast literature on the media and conflict illustrates the connection between these two fields (Eytan 2009). News organisations are, by their nature, connected to politics (Borrat 1989) and they consequently relate to the dynamics of violent political confrontation. The extent to which they should be involved in conflict and post-conflict politics is however unclear. This role contains a paradox: one of the basic principles of journalism refers to its independence, but at the same time, complete objectivity, particularly in divided and contentious societies, is an unachievable goal. The first part of the article outlines the concepts of the media and transitional justice, whereas the second part explores the interconnections between the two fields. 


\section{The crossroads between transitional justice and the news media}

The link between transitional justice and the media can be contextualised within previous studies. The theoretical background of most of the research is based on the work conducted by the scholar Johan Galtung, who conceptualised the term peace journalism as opposed to war journalism (2013). The rationale behind this area of research is clear: since the media "mediates public discussion around transitional justice processes", it is also the media who "decides what will reach the public domain, whose voice will be represented and whether the focus will be on the substance - the circumstances and the causes of the abuse - or on the marginal" (Hodzic and Tolbert 2016: 10). Nevertheless, most of the time, research examining news coverage understands the media's role as an observer of the transitional justice process and places its significance on the ways the media "sells" and "explains" mechanisms and policy. According to Price and Stremlau (2012), the following are some of the other issues to take into consideration:

"... attention must be paid to a myriad of issues, including how the local media function, how journalists (both private and government) frame the patriotic grain, and how they build trust between key actors by serving as a forum for elite negotiation, mediating competing ideas of justice, and strengthening or weakening other group approaches to violence and conflict resolution" (2012: 1081).

The following section analyses the role of the media through four key themes: the role of the media in truth processes, media accountability and press freedom, reparations for journalists and, finally, the significance of media agency in conflict transformation processes.

\section{How can the media mediate transitional justice? Exploring complex and changing concepts}

Transitional justice is commonly defined as "the conception of justice associated with periods of political change, characterized by legal responses to confront wrongdoings of repressive predecessor regimes" (Teitel 2000: 69). Nevertheless, the current understanding of transitional justice goes beyond legal responses (McEvoy 2007) and encompasses, according to the definition provided by the UN, "the full range of processes and mechanisms associated with a society's attempts to come to terms with a legacy of large-scale past abuses, in order to ensure accountability, serve justice, and achieve reconciliation" (UN 2010: 2).

The initial steps in the field were connected with the democratization processes in Latin America in the 1980s, yet most authors trace the initial steps back to the post-war tribunals in Nuremberg and Tokyo (Arthur 2009).Currently, general consensus exists regarding the need for a transitional justice model that includes a holistic 
(comprehensive) approach (Olsen et al. 2010; Nagy 2008) which does not impose "white man's justice," (Lincoln 2011; Andrieu 2010), takes into account culturally diverse communities (Brown and Ní Aoláin 2015), includes a gender perspective (Bell and O'Rourke 2007; Baines 2011) and, above all, is context-specific (Teitel 2014; McEvoy and McGregor 2008).

Furthermore, since the political transitions of the 1990s, several NGOs and international organisations have established communication and media related strategies in postconflict places (Melone et al. 2002). Media connected with peace journalism has also expanded, with the news platform iPacifista!, from Colombia, being an example of this. In recent years, transitional justice specific media outlets have also emerged, such as the platform JusticeInfo.net, which aims at reporting on topics related to international transitional justice. Academics have also expanded research on the links between new information technologies and conflict (Zeitzoff 2018). Initially, the Arab Spring was the focus of most of the studies examining this connection (Hänska Hay 2016), although now this relationship is approached from many different perspectives. Social media and activism (Kavada 2015) and the impact of new technologies in promoting hate speech (Ben-David, Anat and Matamoros-Fernandez 2016) are some of the areas that are based on this view. Yet, as Laplante and Phenicie pointed out, "despite the plethora of academic and scholarly literature" in these fields, "the role and influence that the media has in these processes remain largely unexplored" (2009: 252).

\section{Complexities of today's media}

The golden era of television (the $80 \mathrm{~s}$ and $90 \mathrm{~s}$ ) is fading away and the impact, possibilities and regulation of social media is still unclear. The digital transition has brought new challenges to news organisations: the gap between citizens and journalists is getting smaller every day and new forms of interaction in the digital age are also transforming the impact of the media on politics. The new communication strategies of political leaders and the new challenges related to fake news illustrate the impact of the digital transformation on politics. The way that the US president Donald Trump uses Twitter and the so-called post-truth phenomena are the clearest examples of this trend. Eytan (2010: 87) explains this change further:

\footnotetext{
"Governments have lost much of their monopoly on information, and nonstate actors and individuals have become much more active and significant participants in world affairs, both in warfare and conflict resolution".
}

In spite of the research gap regarding the media and post-conflict politics, the link between the media and conflict has been widely examined, particularly during the 1990s, when the CNN effect was conceptualised. This term implies that global television networks, such as $C N N$ and $B B C$ World, had become decisive actors in determining policies (Eytan 2005). The concept was used at the end of the Cold War, a period marked by several wars, most of them inter-state conflicts (Eytan et al. 2016). 
Since the 1990s, however, the media has changed dramatically. We have reached a situation of 24-hour news that we receive from many different channels (Cushion et al. 2015). Traditionally, the media has been associated with the quality of democracy and the watchdog role. Yet, in transitional contexts, this is "more complex, contested, and potentially more dangerous" (Viebach et al. 2016: 38). Post-conflict scholars and practitioners assume there is a need to use communication technologies to promote freedom of speech, conflict transformation, democratization and development. However, Schoemaker and Stremlau (2014) argue that "it is unclear how and in what cases" this policy should be put forward.

This article builds upon those of other scholars who have created theory in this area. Eytan, for instance, distinguished five levels of the media by geopolitical criteria: "local, national, regional, international, and global" (Eytan 2009: 103). Later, the same scholar added that two aspects must be considered: "(1) the multiplication and fragmentation of media outlets and their subsequent impact upon twenty-first-century news gathering technology; and (2) the role of local media such as outlets based in conflict districts or regions, or national media that cover conflicts in their immediate periphery" (Eytan et al. 2016: 656).

Transitional justice institutions design outreach and communication strategies and make use of new media platforms to reach their audiences (the ICC has its own YouTube channel). On the other hand, news media have the duty to inform about these transitional justice mechanisms. However, transitional justice practitioners usually think journalists are biased and politicised, whereas journalists complain about the limited information delivered by transitional justice institutions (Viebach 2016: 55). Since systems of communication are essential for building trust within and with transitional justice mechanisms (Price and Stremlau 2012: 1081), a transparent healthy relationship between the two sectors seems to be one of the elements for the success of the transformation process.

\section{Tensions in dealing with transitional justice: the truth process}

Transitional justice and the media share the duty of truth: the truth process concerning past human rights violations is at the centre of transitional justice processes and, similarly, the media has a social responsibility in terms of both truth seeking and truth telling. According to communication theory, social responsibility is one of the four traditional theories of the press (Siebert et al. 1963), the other three being the SovietCommunist theory (media solely controlled by the State), Authoritarian theory (strict State control) and Libertarian theory (absence of any State control). The media systems framed within the Social responsibility theory have a duty towards investigative journalism and they are not subject to censorship. This theory includes external and internal mechanisms of media control: codes of conduct for journalists is the clearest example of these mechanisms. A certain tension, however, exists within the social responsibility theory: too much control by State-led organisations can lead to a lack of freedom of speech, controlled narratives and criminalization of alternative historical 
narratives; whereas, on the other hand, a lack of regulation can lead to revisionist narratives (Belavusau 2015).

Societies transitioning from conflict, dictatorship or serious and systemic human rights violations are particularly sensitive to manipulation as there will always be actors trying to hide past violence. In these contexts, there is a particular need to stress the social responsibility of the media and its duty to tell the truth. This responsibility for truth goes beyond reporting and frames the media as an actor in the overall democratization and reconciliation process. In its truth seeking role, according to Ware, media narratives must be "rooted in facts" and should avoid using a "language that doesn't admit to the limitations of what few new facts are ever likely to see the light of day anyway" (Ware 2017: 17). To that end, Barbeito argues that one of the key aspects refers to writing the news "using a variety of sources", such as the judiciary, academics, archives, NGOs and other news organisations (2009: 53).

Rather than the media as a truth-seeking mechanism, the research studying the media and transitional justice has focused on reporting. News coverage of the proceedings and outcomes of Truth and Reconciliation Commissions (TRCs) has been one of the most researched topics. In fact, the way the media behaves during transition is critical in places attempting to deal with a violent past (Laplante and Phenicie 2010). In South Africa, for example, the media played an instrumental role in the early successes of the country's TRCs (Verdoolaege 2005; Krabill 2001). In contrast, news coverage of the TRC in Peru had a negative impact upon the process. According to Laplante (2009: 252), the media in Peru failed "to adequately mediate conflicting views of a country's history - its causes and consequences, its villains and heroes". Thus, news media coverage may exacerbate conflict and undermine attempts at peace building, but it also has the potential to function as a tool of conflict resolution through public education (Nagy and Gillespie 2015: 5).

The role of the media in truth seeking and building narratives on the past (news coverage) can change over time, especially during transition. For instance, Nagy and Gillespie (2015) conclude that the attitude of the media changed regarding news coverage of abuse committed in Indian residential schools in Canada. However, they also point out that newspaper coverage "still falls quite short of challenging Canadians to think about Indian residential schools in expansive terms that frame reconciliation as requiring decolonization and systemic change" (2015: 37).

Traditionally, the media has assumed one of the most significant roles of investigating the conditions in which human rights violations have taken place (Barbeito 2009: 47). In the past, the monopoly of mediated truth lay with journalists and powerful news organisations, but, with the transformation of the media and the expansion of citizen led news coverage, this realm is also constantly evolving. The role of the media does not seem to focus solely on giving news anymore, but on offering context to stories and creating narratives. In addition, there are currently several actors sharing the responsibility towards truth in transitional places: the actors involved in the conflict, the media and, due to the emergence of social media and other new technologies, citizens too. In recent years, new platforms and mobile applications have emerged to help citizens uncover these types of abuse, such as People's Intelligence (PI) and Eyewitness, which 
seek to encrypt videos and protect authors to be able to use this data as evidence in court cases.

\section{Towards society: accountability and press freedom}

Two of the critical aspects in a transitional justice process are the initiatives to unveil the truth and accountability mechanisms. Transitional justice generally looks at the traditional actors in conflicts, such as armed groups and State controlled forces, but it can also look at third parties, such as business companies and the media. As the field expands, the performance of these third-party actors is also being held accountable. Moreover, there are some precedents of this practice in the 1990s, in South Africa and Rwanda. One of the institutional hearings held in the TRC in South Africa studied the role of the media, and the media case in Rwanda (The Prosecutor v. Nahimana, Barayagwiza and Ngeze) is one of the most well-known cases of media accountability. In this case, three individuals connected to Radio Télévision Libre des Mille Collines (1993-4) and the Kangura newsletter (1990-95) were prosecuted, allegedly as the masterminds behind a media campaign to desensitize the Hutu population and incite them to murder the Tutsi population. In 2003, the Trial Chamber found all three defendants guilty of genocide, conspiracy to commit genocide, direct and public incitement to commit genocide, persecution, and extermination as crimes against humanity (Thomson 2007). However, after several appeals and procedural mistakes, the Appeals Chamber reversed some aspects of the Trial Judgment and acquitted all three of conspiracy to commit genocide and extermination as a crime against humanity. Two of the prosecuted were still found guilty of direct and public incitement to commit genocide. Although most of the media accountability cases (i.e. when media holds political responsibility of the events) will not go as far as being involved in genocide, an analysis of media responsibility during conflict should form part of the overall strategies of dealing with the past.

The lines separating propaganda war, media crimes and freedom of press and speech are sometimes blurred. Along with the boom in memory laws passed in recent years, terminology related to violence and the past has been banned in several places. In 2018, for instance, Poland outlawed the use of the term Polish death camps in the new legislation passed about the Holocaust. The aim of this initiative was to avoid any accusation of the country's complicity in crimes committed by Nazi Germany. In an attempt to criminalise certain terms and concepts (particularly, in social media), Spain passed a National Security Law in 2015 that considerably expands the crime of 'the glorification of terrorism'. Under this law, for instance, comments made on Twitter which have been considered offensive to victims of terrorism and the monarchy have been punished with jail sentences. It is yet unclear how news information and personal opinions can promote hate speech and other forms of discrimination and, particularly in the context of the digital age, these debates overlap with attacks on freedom of speech. The contestation of the past in societies facing transitional justice processes intertwines with initiatives to protect victims but also with the right to freedom speech and press. The roles of the media in transitional societies are caught up in this backdrop of changing media systems and institutional initiatives to control what it is acceptable to say, and what it is not. 


\section{Towards journalists themselves: trauma and reparation}

Although journalists can commit crimes in their professional practice, the reality is that most of the media-related crimes are actually in the form of abuse against journalists. The freedom of the press is always violated in places of conflict or/and dictatorships and, consequently, measures concerning its restoration are usually found in the transitional agenda. Legislation to guarantee these liberties (freedom of speech and freedom of the press) is the most common mechanism to promote the democratization of the past, however, in recent times, reparations for journalists who have suffered abuse are also becoming part of the transitional justice package.

The right to reparation for victims of serious human rights violations has expanded along with transitional justice literature. Today it is widely assumed that transitional societies have to establish reparation programmes for victims of political violence. Transitional justice has become victim-centred and most of its mechanisms have developed strategies to consider victim participation and visibility (May and Edenberg 2013). Despite the concept of reparation being broad, the UN understands that it can have an individual and collective approach, and include measures for restitution, compensation, rehabilitation, satisfaction and guarantees of non-repetition (UN 2006).

When it comes to reparations for journalists, one of the key aspects that arises is the type of reparation they should receive. Individual reparations for journalist victims are not in doubt, but the collective dimension of these initiatives falls into a controversial area. Yet, there are two dimensions to violence against journalists that justify the collective nature of these abuses: violence against journalists can be used as a war weapon, and this violence also represents an attack on the freedom of the press and the right of a community or a society to receive information (FLIP 2015: 13). For instance, Colombia's Victims Law (2011) opened up the possibility of granting collective reparations to journalists (also to indigenous communities and other groups).

One aspect to be taken into account in this respect is the need for a comprehensive approach to violence and reparations for journalists, including a gender perspective, as well as a cultural diversity view in this conceptualisation and practice. In this sense, the International Women Media Foundation recommends considering how gender inequality and sexist practices manifest themselves in the phenomenon of violence against journalists (Botero Marino 2013: 155).

Another aspect that connects news media with reparations refers back to news coverage. So far, we have referred here to official and State-led reparations, but the transitional justice process and the reparative nature of past violations should also take a bottom-up approach (McEvoy and McGregor 2008). In this sense, news organizations have a critical role to play in giving a voice to victims and to people's silenced stories. Transitional justice can take a variety of forms and storytelling - that is, to give voice and visibility to certain individuals or groups- can work as recognition and reparation itself. In this direction, Hodzic and Tolbert argue that "sharing victims' stories can be a form of restoration, a relief from the harm they suffered (another principle at the heart of transitional justice), and even a catalyst for broader public acknowledgment." (2016: 5). 


\section{Looking forward: Media agency in the transformation process}

Apart from truth, justice and reparations, guarantees of non-repetition is the fourth angle of transitional justice. Although many different strategies and mechanisms can be established to pursue guarantees of non-repetition (the overall transitional justice process seeks this end), most of the literature connects this principle with DDR (Disarmament, Demobilization, Reintegration) processes, institutional reform and measures for building democracy and reconciliation. A wide range of measures could be included in this area, but, in terms of the media, we find two interconnected strategies seeking to promote media agency in these processes: media reform and media assistance.

According to Martin (2011), media reform covers both the transformation of the system and measures to assist journalists and the media. In his research about media reform in Bosnia, he identified four key areas of activity: journalism education, media business development, free speech and the protection of journalists, and the creation of associations and networks of media professionals designed to develop professional standards and codes of conduct (Martin 2011: 86). Although all these elements relate to media reform, from a transitional justice perspective it seems necessary to distinguish between efforts that pursue the democratization of the system itself (media reform) and the measures directed to improve the quality of journalism practice (media assistance).

Transitional justice literature highlights that the processes should be context specific and led by local actors, rather than directed by the international community through onesize-fits-all formulas. If we apply this idea to the reform of the media system, this process has to aim at ensuring plurality and the participation of different communities and groups. For these reforms to be transformative, the promotion of community media and initiatives to regulate media concentration seem necessary. The recent peace agreement in Colombia (2016), for instance, includes a new call to deliver community radio licences (Point 2.2.3 of the Final Accord) and new regulations for assigning institutional advertising (Point 2.2.3.2). ${ }^{1}$

A fully comprehensive media reform strategy will have to look at the media system in a holistic way. In addition, legislation on press freedom and freedom of speech may be revised and adapted to the new digital landscape, and issues regarding media access will have to be reconsidered. The limitations of some countries to access social media (Turkey, Iran and Pakistan, for instance) and the technical elements needed to allow this access (only $3 \%$ of the population in Chad have access to the Internet) are issues to consider. In many cases, the models to follow in the media system reform cannot be based on Western models of democracy nor liberal models of independent media (Voltmer 2013). The end aim should be that local actors own the media system and they follow the rules of public interest, rather than the interests of the political and economic elite.

In order to achieve these aims, media assistance also has a role to play: professionalism, as pointed out above, is critical in ensuring the social responsibility of the media. These

1 The final peace agreement was signed on the 24th November 2016. 
strategies can take many different forms: training for journalists, technical assistance for news organisations, supporting the establishment of entities such as complaints commissions and ombudsmen, promoting networks for media workers and codes of conduct/best practices and guidelines for journalists. Several codes of conduct and ethics for journalists during conflict exists (see, for instance, the UNESCO's principles for journalists covering conflicts, from $1978^{2}$ ), but there is a need to promote new norms covering the specific challenges in post-conflict sites. The European Union, for instance, included the preparation of a TRC Journalists' Code of Conduct in its journalist training programme (Price and Stremlau 2012) and new draft guidelines for journalists were presented in Northern Ireland in May $2018^{3}$. In a similar vein, a set of norms have been agreed in Bojayá, Colombia, in order to establish a code of conduct for journalists covering exhumations. These guidelines are an attempt to balance the victims' right to intimacy and the right to information of journalists and communities (Newman Pont et al., 2018).

Ultimately, the purpose of media reform and assistance is to promote democratization by facilitating the free flow of information, transparency, accountability in the government, and economic growth (Kumar 2007). In order to promote media agency in the transitional justice process, media reform should be part of the overall conflict transformation strategy.

\section{Conclusion}

Anderson's concept of imagined communities (1989) has been widely used in cultural and media studies (Tsaliki 1995). A significant part of the way we shape and imagine our societies and communities relates to the way the media frames the news. The media, thus, plays a crucial role in shaping our narratives on the past. When these narratives are part of a divided society, the role of the media is also contested: one or other narrative will be promoted depending on the power relationships within the media system. The realm of transitional justice works in the same way: one or other mechanisms and models for dealing with a violent past will be established depending on who holds hegemonic power. There is, therefore, a direct relationship between the media, transitional justice and the process of constructing narratives, truth, and justice.

The role of the media in building narratives of conflict and past human rights violations was traditionally framed within the dichotomy of promoting peace vs inflicting war. Yet, these roles, as well as the media systems themselves, need to be placed within more complex frameworks. This article has analysed some of the key themes that connect transitional justice (the right to truth, justice, reparations and guarantees of nonrepetition) and the media. The primary conclusion is that we need to go beyond the role of the media as an observer, and frame it as a possible agent of the overall process of conflict transformation and transitional justice. This agency can, however, be flawed if

2 UNESCO, Declaration on Fundamental Principles concerning the Contribution of the Mass Media to Strengthening Peace and International Understanding, to the Promotion of Human Rights and to Countering Racialism, apartheid and incitement to war, adopted on the 28th November 1978.

3 The draft guidelines were launched in the 'Victimhood and dealing with the Past' conference at Queens University Belfast, held on the14th May 2018. 
the media does not use appropriate genres and ethics (Rolston, 2007); for this reason, further guidelines that focus on media agency are critical. There is also a need to give value to the social responsibility theory of news organisations in transitional contexts in order to find the right balance between press freedom and accountability.

This article has examined some of the different roles that connect the media with transitional societies. In the light of transitional justice, media strategy in transitional societies should be as follows: comprehensive (consider all the actors involved in the media system); transformative (democratization of the media landscape should include mechanisms against concentration of media and regulation of institutional advertising, for instance); context-specific (local actors should own and direct the strategies) and bottom-up (community media that does not follow political and economic interests should be encouraged). In conclusion, the link between transitional justice and the media lies in the fact that the conflict and past human rights abuse cannot be told or narrated solely by one set of actors. In the process of building truth and narratives on the past, the media has to consider giving a voice to victims, perpetrators, academics and civil society organisations (Newman Pont et al. 2018).

\section{References}

Anderson, B. (1983). Imagined Communities. Reflections on the origin and spread of nationalism. London: Verso.

Andrieu, K. (2010). Civilizing Peacebuilding: Transitional Justice, Civil Society and the Liberal Paradigm. Security Dialogue 41(5): 537-555.

Arthur, P. (2009). How "Transitions" Reshaped Human Rights: A Conceptual History of Transitional Justice. Human Rights Quarterly 31(2): 321-367.

Barbeito, J. (Fundación para la Libertad de Prensa. FLIP). (2009). Manual sobre periodismo y justicia transicional. Oportunidades y desafíos para el periodismo regional en Colombia. Manuales FLIP.

Belavusau, U. (2015). Memory Laws and Freedom of Speech: Governance of History in European Law. In: Koltay A (ed.) Comparative Perspectives on the Fundamental Freedom of Expression. Wolters Kluwer, pp. 537-558.

Bell, C, and O'Rourke, C. (2007). Does Feminism Need a Theory of Transitional Justice? An Introductory Essay. International Journal of Transitional Justice (1): 23-44.

Ben-David, A., and Matamoros-Fernandez. (2016). Hate speech and covert discrimination on social media: Monitoring the Facebook pages of extreme-right political parties in Spain. International Journal of Communication 10: 1167-1193.

Baines, E. (2011). Gender, Responsibility, and the Grey Zone: Considerations for Transitional Justice. Journal of Human Rights 10(4): 477-493.

Borrat, H. (1989). El periódico, actor del sistema político. Anàlisi 12: 67-80.

Botero Marino, C. (2013). Violence against journalists and media workers: InterAmerican standards and national practices on prevention, protection and prosecution of 
perpetrators. Office of the Special Rapporteur for Freedom of Expression Inter-American Commission on Human Rights. Inter-American Commission of Human Rights.

Brown, K., and Ní Aoláin, F. (2015). Through the Looking Glass: Transitional Justice Futures Through the Lens of Nationalism, Feminism and Transformative Change. International Journal of Transitional Justice 9: 127-149.

Buckley-Zisteil, S., and Koloma Beck, T. (eds.) (2015). Transitional Justice Theories. Routledge.

Cushion, S., Lewis, R. and Roger, H. (2015). Adopting or resisting 24-hour news logic on evening bulletins? The mediatization of UK television news 1991-2012. Journalism 16(7): 866-883.

De Greiff, P. (2012). Theorizing Transitional Justice. In M. S. Williams, R. Nagy, and J. Elster (eds.), Transitional Justice. New York University Press.

FLIP, Fundación para la Libertad de Prensa (2015). 6 pasos para la reparación colectiva a periodista. Bogotá: FLIP.

Galtung, J. and Fishcher, D. (2013). Johan Galtung. Pioneer of Peace Research. Springer. Series: SpringerBriefs on Pioneers in Science and Practice. Vol. 5.

Gilboa, E. (2009). Media and Conflict Resolution: A Framework for Analysis. Marq. L. Review 93: 87-110.

Gilboa, E. (2005). The CNN Effect: The Search for a Communication Theory of International Relations. Political Communication 22: 27-44.

Gilboa, E., Gabrielsen Jumbert, M., Miklian, J. and Robinson, P. (2016). Moving media and conflict studies beyond the CNN effect. Review of International Studies 42(4): 654672.

Gready, P. (2010). The Era of Transitional Justice. Routledge.

Haldemann, F. (2008). Another Kind of Justice: Transitional Justice as Recognition. Cornell International Law Journal 41: 675-737.

Hänska Hay, M. (2016). Networked communication and the Arab Spring: Linking broadcast and social media. New Media and Society 18(1): 99-116.

Hodzic, R. and Tolbert, D. (2016). Media and Transitional Justice. A Dream of Symbiosis in a Troubled Relationship. ICTJ Briefing. The International Center for Transitional Justice.

Kavada, A. (2015). Creating the collective: social media, the Occupy Movement and its constitution as a collective actor. Information, Communication and Society 18(8): 872886.

Krabill, R. (2001). Symbiosis: Mass Media and the Truth and Reconciliation Commission of South Africa. Media, Culture and Society 23(5): 567-85.

Kumark, K. (2007). International Assistance to Promote Independent Media in Transition and Post-conflict Societies. Democratization 13(4): 652-67. 
Laplante, L. J., and Phenicie, K. (2009). Mediating Post-Conflict Dialogue: The Media's Role in Transitional Justice Processes. Marq. L. Rev. 93: 251-283.

Laplante, L. J., and Phenicie, K. (2010). Media, Trials and Truth Commissions: 'Mediating' Reconciliation in Peru's Transitional Justice Process. The International Journal of Transitional Justice 4: 207-229.

Lincoln, J. (2011). Transitional Justice, Peace and Accountability. Outreach and the Role of International Courts After Conflict. Routledge.

Louise Sooka, Y. (2010). The Politics of Transitional Justice. In: Lekha Sriram C and Pillay $\mathrm{S}$ (eds.) Peace versus Justice? The Dilemma of Transitional Justice in Africa. James Currey.

Martin, E. C. (2011). Media Reform and Development in Bosnia: An Interorganizational Account of the Media Issues Group. South East European Journal of Economics and Business 6(1): 85-98.

May, L., and Edenberg, E. (eds.) (2013). Jus Post Bellum and Transitional Justice. Cambridge University Press.

McEvoy, K. and Mallinder, L. (2017). Transitional Justice. Routledge.

McEvoy, K. (2007). Beyond Legalism: Towards a Thicker Understanding of Transitional Justice. Journal of Law and Society 34(4): 411-440.

McEvoy, K., and Mcgregor, L. (2008). Transitional Justice from Below: Grassroots Activism and the Struggle for Change (Human Rights Law in Perspective). Hart Publishing.

Melone, S., Terzis, G., and Beleli, O. (2002). Using the media for conflict transformation. The Common Ground Experience. Berghof Handbook for Conflict Transformation.

Nagy, R. (2008). Transitional Justice as a Global Project: Critical Reflections. Third World Quarterly 29 (2): 287-289.

Nagy, R., and Gillespie, E. (2015). Representing Reconciliation: A news frame analysis of print media coverage of Indian residential schools. Transitional Justice Review 1(3): Article 2.

Newman Pont, V., Ángel Arango, M.P., and Dávila Contreras, M. X. (Dejusticia) (2018). Víctimas y prensa después de la guerra. Tensiones entre intimidad, verdad histórica y libertad de expresión. Documentos Dejusticia 4. Centro de Estudios de Derecho, Justicia y Sociedad, Dejusticia.

Olsen, T.D., Payne, A., and Reiter, A. G. (2010). Transitional Justice in Balance. United States Institute of Peace.

Price, M., and Stremlau, N. (2012). Media and Transitional Justice: Toward a Systematic Approach. International Journal of Communication 6: 1077-1099.

Rolston, B. (2007). Facing reality: The media, the past and conflict transformation in Northern Ireland. Crime, Media and Culture 3(3): 345-364 [DOI:
[D 10.1177/1741659007082470].ç 
Siebert, F. S., Peterson, T. and Schramm, W. (1963). Four Theories of the Press: The Authoritarian, Libertarian, Social Responsibility and Soviet Communist Concepts of What the Press Should Be and Do. University of Illinois Press.

Schoemaker, E., and Stremlau, N. (2014). Media and conflict: An assessment of the evidence. Progress in Development Studies 14(2): 181-195.

Tamayo, C. and Bonilla, J. (2014). El deber de la memoria. La agenda investigativa sobre la cobertura informativa del conflicto armado en Colombia, 2002-2012. Palabra Clave 17(1): 13-45.

Teitel, R. (2000). Transitional Justice. New York: Oxford University Press.

Teitel, R. (2014). Globalizing Transitional Justice. Contemporary Essays. Oxford University Press.

Thomson, A. (2007). The Media and the Rwanda Genocide. London: Pluto Press.

Tsaliki, L. (1995). The Media and the Construction of an 'Imagined Community'. The Role of Media Events on Greek Television. European Journal of Communication 10(3): 345-370.

United Nations (2005). Basic Principles and Guidelines on the Right to a Remedy and Reparation for Victims of Gross Violations of International Human Rights Law and Serious Violations of International Humanitarian Law. UN Doc. A/RES/60/147 (See Section IX) (Geneva, Switzerland: United Nations).

United Nations Guidance Note of the Secretary-General. (2010) United Nations Approach to Transitional Justice. March 2010.

Verdoolaege, A. 2005. Media representations of the South African Truth and Reconciliation Commission and their commitment to reconciliation. Journal of African Cultural Studies 17(2): 181-199.

Viebach, J., Ullrich, L., Gawronski, M., and Hoyle, C. (2016). Innovative Media for Change. Opportunities and Challenges of Media Collaboration in Transitional Justice. Report. Oxford Transitional Justice Research/Centre for Criminology: University of Oxford.

Voltmer, K. (2013). The media in transitional democracies. Cambridge/Malden: Polity Press.

Ware, J. (2017). How can journalism help Northern Ireland come to terms with 'the past'? Queens University Belfast Human Rights Centre Occasional Paper Series.

Zeitzoff, T. (2018). Does Social Media Influence Conflict? Evidence from the 2012 Gaza Conflict. Journal of Conflict Resolution 62(1) 29-63. 